Research Article

\title{
INVESTIGATING THE UTILIZATION OF WASTE GLASS POWDER, COLEMANITE ORE WASTE AND SUGAR FACTORY FILTER CAKE IN GYPSUM-LIME BASED MORTARS
}

\section{Muhammed Yasin DURGUN ${ }^{1}$}

\begin{abstract}
The wastes generated by the recent industrial developments threaten the future of the world. Therefore, researches on the recycling of the industrial wastes in various ways are increasing day by day. In this study, glass powder, a waste of glass industry, colemanite ore waste, a by-product of boron industry and filter cake, one of the wastes of sugar factories, were used. The evaluation of these wastes in gypsum and lime based mortars has been investigated. In this study, 10, 20 and 30\% of the waste materials were used instead of gypsum. Unit weights, ultrasonic pulse velocities, apparent porosities and thermal conductivity coefficients of the gypsum-lime based mortars were determined. Compressive strength and bending strength tests were performed to determine the mechanical properties. The results indicated that the use of wastes negatively affected the mechanical properties while improving the thermal properties.
\end{abstract}

Keywords: gypsum, lime, waste glass powder, colemanite ore waste, sugar factory filter cake

\section{Introduction}

Gypsum is one of the most preferred building materials in the world. It is used frequently due to its good acoustic performance, fire prevention, moisture balance of building elements and natural, organic and environmentally friendly properties [1]. Besides, it is easy and cheap to produce. However, the fact that the plaster is very brittle and non-resistant to cracking makes it difficult to use as exterior material [2]. For this reason, in some applications, it has been aimed to improve some mechanical properties by adding reinforcing materials such as various fibers or aggregates into gypsum mixtures and it has even been made available as plates [3].

Lime is one of the most traditional binders used in the world for centuries. In the last few decades, it has attracted more attention due to its mechanical strength, modulus of elasticity and water vapor permeability. At the same time, it has become one of the alternative binders for cement due to its more embodied energy and greenhouse gas emission. Thus, research on lime products, lime-based mortars and injections have increased $[4,5]$.

Today, to reduce environmental hazards arising from the production of Portland cement, researches have focused on obtaining economic binders using industrial by-products and wastes (blast furnace slag, silica fume, fly ash) and natural resources (natural pozzolans, lime, gypsum, calcined clays). Because the factors that triggered global warming have become one of the most fundamental problems [6]. The use of some industrial wastes as mineral additives with Portland cement has become

\footnotetext{
${ }^{1}$ Department of Civil Engineering, Bartın University, Bartın, Turkey, (mydurgun@bartin.edu.tr) (Dhttps://orcid.org/0000-00034656-9430 
very popular for this purpose. In this way, energy consumption is reduced, the economy is provided, ecological balance and natural resources are protected [7].

Gypsum is a material that hardens when it reacts with water. The water used in gypsum mixtures can be divided into two parts. The first part is the part necessary for the gypsum to be hydrated. The second part is the part that necessary for achieving the workability. The second part of the water constitutes a large part of the water added to the mixture and will then leave the structure in the air voids, depending on age and drying. The use of high amounts of water causes negativity in terms of mechanical properties [8].

In the literature, it is seen that the use of different additives to improve the physico-mechanical and hydrophobic properties of gypsum-containing mixtures to keep their structure together against deterioration. For example, Wang et al. [9], evaluated the use of metakaolin in gypsum-lime mixtures, while Morsy et al. [6] evaluated the use of fly ash as well as metakaolin in gypsum-lime mixtures. Demir and Başpınar [10] investigated the use of silica fume and expanded perlite in fly ash-limegypsum mixtures. Gourav and Reddy [11] produced bricks from gypsum-lime mixtures containing fly ash and investigated their structural performance. Neto et al. [12] conducted studies on the use of blast furnace slag in gypsum and lime mixtures and del Rio Merino et al. [13] worked on the evaluation of ceramic wastes in gypsum mixtures. Khalil et al. [14] used rice husk ash together with slag to improve the properties of gypsum-lime mixtures. In another study, Aubert et al. [15] examined the rate of gypsum and lime consumption in lime-gypsum mixtures using natural pozzolan, silica powder, and waste paper sludge ash.

As can be seen, it has been paid attention that the additives used in the studies are waste and / or show pozzolanic properties. Thus, it is aimed to obtain improved and / or economical products. Pozzolan is the general name of natural of inorganic materials that react in the presence of calcium hydroxide (lime) and water and harden [16]. For this reason, the pozzolanic properties of the additives used to make the idea that they can contribute to the strength. The fact that the material is waste, contributes to environmental protection and enables a more economical mixture to be produced.

According to data from the year 2017, 1.331.265 tonnes of glass packaging is manufactured in Turkey. $23 \%$ of the marketed portion of these produced packages was recycled [17]. According to 2016 data, these values are 99\% in Sweden, 98\% in Switzerland, 96\% in Belgium and 85\% in Germany [18]. Waste glasses are generally stored in solid waste landfills if they cannot be recycled. This causes environmental problems [19]. For this reason, recent studies on the potential of glass wastes in the concrete and cement industry are being conducted frequently. Various researchers are being conducted on the use of waste glass in the aggregate form [20], filler material [21], geopolymer raw material [22] and concrete admixture [23]. Researchers have reported that even if used in small proportions, finely ground glass powder may exhibit more pozzolanic activity than fly ash, which is very common in use [24].

Turkey, as is known, has about $72 \%$ of boron known reserves around the world. Boron is a precious mineral used in industry, energy, and medicine. Turkey is the worlds's second-largest boron and components manufacturer after the United States. The most common boron minerals are colemanite, ulexite, and tincal. These minerals are subjected to various processes in production sites and turned into boric acid and borates in plants. Some by-products are generated from this production and these wastes cause environmental pollution. Colemanite ore wastes resulting from colemanite processing are collected in ponds close to the facility are and create a risk of pollution by mixing with underground water resources [25]. For this reason, studies on the evaluation of colemanite ore wastes 
in the cement and concrete industry have shown that the wastes contribute to the concretes later age strength. Olgun et al. [26], in their study in cement production by using colemanite ore waste instead of gypsum, obtained positive results and reported that a denser microstructure was obtained.

Approximately $65-70 \%$ of the world's sugar production is met by sugar cane [27]. According to 2013 data, annual sugar cane production is $1.877 \mathrm{Mt}$. Approximately $104 \mathrm{~kg}$ of sugar is obtained from $1000 \mathrm{~kg}$ sugar cane harvested after reaching the factory and subjected to various processes, which corresponds to about $13 \%$ of the first crop. The remaining parts are treated as sugar factory wastes. Sugar factories have three main wastes. These are sugar cane pulp, molasses, and filter cake. Up to $52 \%$ of the total product is liquid waste, $28 \%$ is pulp, $3 \%$ is molasses and $4 \%$ is filter cake [28]. The filter cake is a product produced after the purification of sugar water and is one of the main solid wastes of the sugar industry. The safe storage and disposal of this product have always been an important issue. Random storage may cause occupation of space due to stacking, air pollution and groundwater pollution [29]. The basic chemical component of the filter cake is $\mathrm{CaO}$, which is also main component of the lime-based cement components. Therefore, investigations have been made on the usability of filter cake instead of lime-based raw materials in cement clinker production [30]. Li et al. [31, 32] examined the hydration characteristics of the product by using filter cake instead of limebased materials in clinker production and obtained positive results up to certain ratios. It is also seen in the literature that filter cake is used in fields such as soil improvement [33], light foam concrete production [28] and brick production [34].

In this study, waste glass powder (WGP), colemanite ore waste (COW) and sugar factory filter cake (SFC) were used in 10, 20 and 30\% ratios in gypsum-lime based mixtures. The unit weights, ultrasonic pulse velocity values, bending and compressive strengths, apparent porosity values and thermal conductivity coefficients of the produced samples were examined and the evaluability of these waste materials in gypsum applications was investigated. By this way, it is aimed to preserve gypsum sources and to evaluate waste materials in the gypsum-based mixtures.

\section{Materials and Methods}

\subsection{Materials}

WGP used in the study was taken from the waste powders of a glass factory operating in the Kahramanmaraş region. COW was obtained from Bigadiç Boron Plant's wastes. The SFC was taken from Elbistan sugar factory wastes. All wastes obtained was milled in the ball mill and sieved to a size of less than 30 microns. The gypsum used as the main material is commercially obtained, has a specific surface value of $4280 \mathrm{~m}^{2} / \mathrm{g}$ and a density of $2.91 \mathrm{~g} / \mathrm{cm}^{3}$. The lime used in the study was commercially obtained meets with TS EN 459-1. Chemical analysis and images of waste materials used are given in Table 1 and Fig. 1., respectively.

Table 1. Chemical and physical properties of waste materials.

\begin{tabular}{llll}
\hline Compound $(\%)$ & Waste Glass Powder & Colemanite Ore Waste & Sugar Factory Filter Cake \\
\hline Chemical analysis results & & & \\
\hline $\mathrm{SiO}_{2}$ & 72.65 & 34.15 & 2.55 \\
$\mathrm{Al}_{2} \mathrm{O}_{3}$ & 0.76 & 9.96 & 0.83 \\
$\mathrm{Fe}_{2} \mathrm{O}_{3}$ & 0.19 & 5.67 & 0.35 \\
$\mathrm{CaO}$ & 9.36 & 12.05 & 37.66 \\
$\mathrm{MgO}$ & 4.16 & - & 1.21 \\
$\mathrm{SO}_{3}$ & 0.21 & - & 0.21 \\
$\mathrm{Na}_{2} \mathrm{O}+\mathrm{K}_{2} \mathrm{O}$ & 12.88 & - & 0.39 \\
$\mathrm{~B}_{2} \mathrm{O}_{3}$ & - & 19.06 & - \\
$\mathrm{Loss}$ on ignition $(\%)$ & -9.68 & 54.87 \\
\hline Physical analysis results & & \\
\hline Density $\left(\mathrm{g} / \mathrm{cm}^{3}\right)$ & 2.75 & 2.41 & 2.07 \\
Fineness & $<30 \mu \mathrm{m}$ & $<30 \mu \mathrm{m}$ & \\
\hline
\end{tabular}




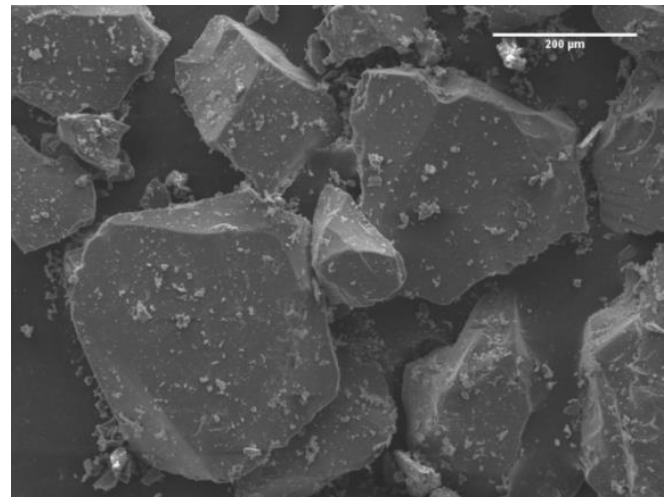

(a) Waste glass powder

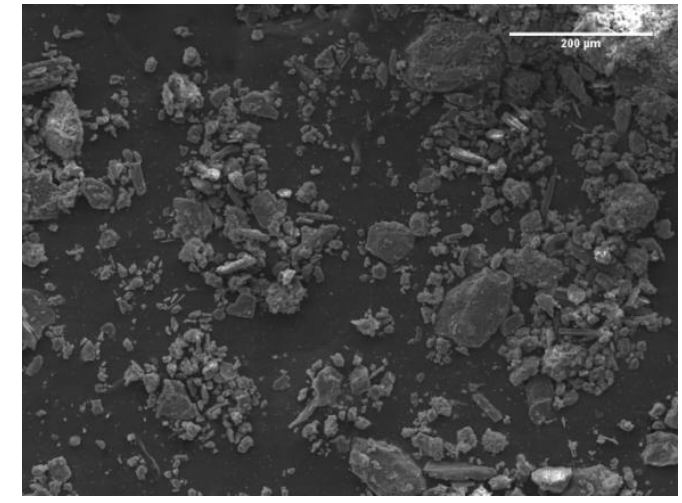

(b) Colemanite ore waste

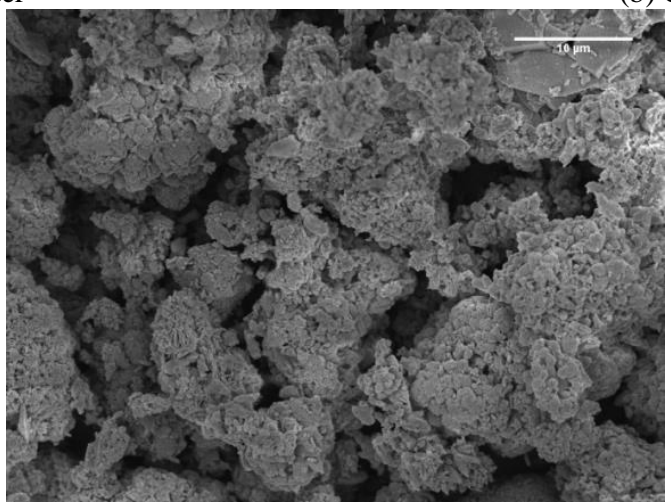

(c) Sugar factory filter cake

Figure 1. Images of waste glass powder, colemanite ore waste and sugar factory filter cake.

As fine aggregate standard CEN sand with a density of $2.63 \mathrm{~g} / \mathrm{cm}^{3}$ and waster absorption of $\% 1.50$ was used. The grain distribution of the standard CEN sand is given in Figure 2.

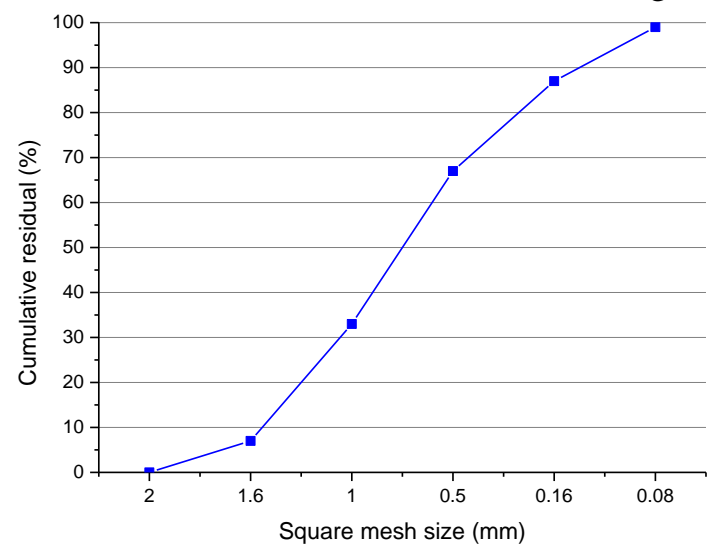

Figure 2. Grain distribution of standard CEN sand.

\subsection{Methods}

The mix design used in the study is given in Table 2. In the table, codes for reference sample, WGP, COW and SFC are "R", "GP", "CW" and "FC", respectively. All waste materials were used in 10, 20 and 30\% by weight instead of gypsum. The mixtures were prepared according to EN 13454-2. Water was poured into the bowl and then gypsum-lime was added. The materials mixed for $30 \mathrm{~s}$ at low speed and the sand added and then mixed 30 more seconds. Finally, the materials mixed for $60 \mathrm{~s}$ at high speed. The fresh mixes were cast into molds of 40x40x160 mm and vibration was applied for 30 seconds. The samples were removed from the molds after 24 hours and kept at $23 \pm 2{ }^{\circ} \mathrm{C}$ and approximately $50 \%$ humidiy for 28 days. 
Table 2. Mix design of waste containing gypsum-lime based mortars (g).

\begin{tabular}{|l|l|l|l|l|l|l|l|}
\hline Code & Gypsum & Lime & Fine Aggr. & WGP & SFC & COW & W/B $^{\mathbf{1}}$ \\
\hline R & 675 & 225 & 1350 & 0 & 0 & 0 & 0.60 \\
\hline GP10 & 607.5 & 225 & 1350 & 67.5 & 0 & 0 & 0.60 \\
\hline GP20 & 540 & 225 & 1350 & 135 & 0 & 0 & 0.60 \\
\hline GP30 & 472.5 & 225 & 1350 & 202.5 & 0 & 0 & 0.60 \\
\hline CW10 & 607.5 & 225 & 1350 & 0 & 0 & 67.5 & 0.60 \\
\hline CW20 & 540 & 225 & 1350 & 0 & 0 & 135 & 0.60 \\
\hline CW30 & 472.5 & 225 & 1350 & 0 & 0 & 202.5 & 0.60 \\
\hline FC10 & 607.5 & 225 & 1350 & 0 & 67.5 & 0 & 0.60 \\
\hline FC20 & 540 & 225 & 1350 & 0 & 135 & 0 & 0.60 \\
\hline FC30 & 472.5 & 225 & 1350 & 0 & 202.5 & 0 & 0.60 \\
\hline
\end{tabular}

At the end of this period, the samples were kept in the oven at $40{ }^{\circ} \mathrm{C}$ for 24 hours and free moisture was removed. The samples were then subjected to unit weight, ultrasonic pulse velocity (UPV) (ASTM C597), thermal conductivity (ASTM D7984), compressive strength, and bending strength tests (TS EN 13279-2). Some samples were saturated with water and the amount of water absorption was determined, as well as the apparent porosity values were measured using the Archimedes method (ASTM C20).

\section{Results and Discussion}

\subsection{Unit Weights}

The unit weights of the samples are shown in Figure 3.

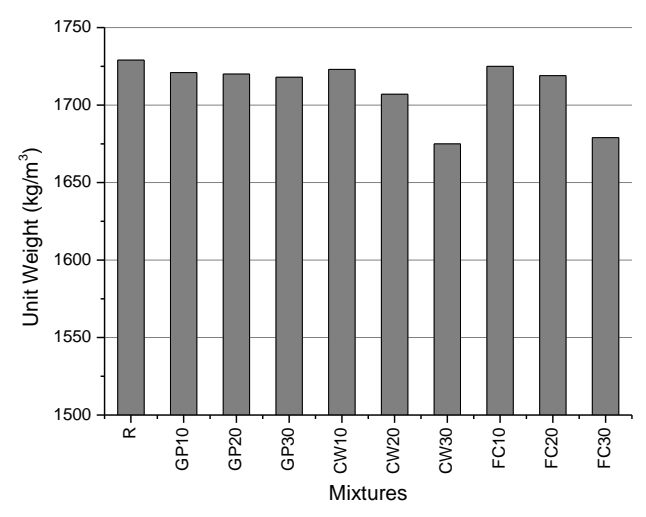

Figure 3. Unit weight results.

The unit weight values varied between $1675-1729 \mathrm{~kg} / \mathrm{m}^{3}$. The highest value was obtained from the sample R, which does not contain any waste material. The lowest value was obtained from $30 \%$ COW containing sample. From Figure 3, it can be obviously seen that waste incorporation decreased the unit weights of the gypsum-lime based samples. The effect of COW and SFC is more effective than WGP, especially at higher percentages. The unit weight decreased $\% 3.1$ at most, which is obtained from CW30. It can be concluded that waste addition decreased the unit weight but the level of the reduction is not very significant. The reason of the decrease of the unit weight can be related to the reactions of the waste materials. It is believed that due to unreacted particles, sufficient development in the paste phase does not occur and a more porous structure formed. This situation discussed again in section 3.3. and 3.5.

\subsection{Ultrasonic Pulse Velocity}

Ultrasonic pulse velocity (UPV) results are given in Figure 4. The relation between UPV and apparent porosity of the samples is given in Figure 5. 


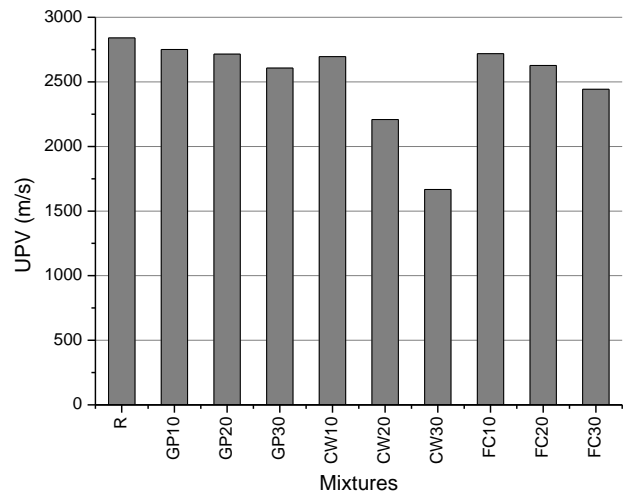

Figure 4. Ultrasonic pulse velocity results.

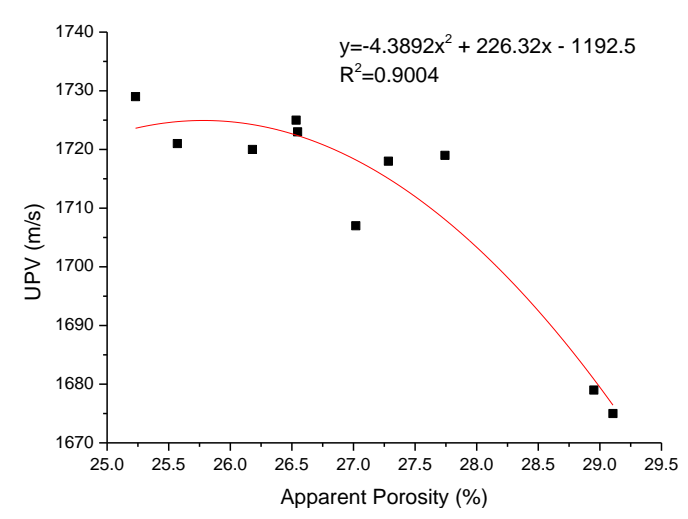

Figure 5. Apparent porosity and UPV relation.

The ultrasonic pulse velocity values varied between $1667-2841 \mathrm{~m} / \mathrm{s}$. The highest value obtained from sample R and the lowest value obtained from CW30. The UPV values of all waste added gypsum-lime based mortars decreased compared to R. However, the decrement in WGP and SFC is not as significant as COW containing samples. Especially higher amount of COW incorporation, $20 \%$ and $30 \%$, changed the value $11 \%$ and $32 \%$. It is known that the ultrasonic pulse velocity is strongly related to the pore structure of the material. The velocity of the ultrasonic waves in the body is slowed down by the high amount of voids, and it is higher in low-void bodies. The results can be evaluated that as the increase in the amount of COW, the pore structure increases. As can be seen from Figure 5, there is a strong relation between them and while the porosity increases the UPV decreases.

\subsection{Apparent Porosity}

The apparent porosity values of the samples are given in Figure 6.

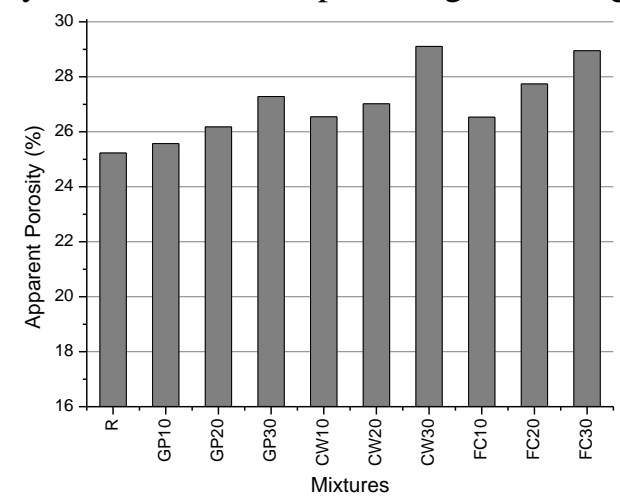

Figure 6. Apparent porosity of the samples.

The porosity values of gypsum-lime based mortars varied between $25.2 \%-29.1 \%$. Tesch and Middendorf [35] studied porosity values of many different gypsum-lime based mortars at different storage conditions and found that the values obtained varied between approximately $17 \%-34 \%$. As can be seen from Figure 6, the highest porosity value obtained from the CW30 sample. The lowest porosity value belongs to sample R. In section 3.2. it was mentioned about the relation between porosity and UPV. According to the results, all waste containing samples have higher porosity value than the R sample. Samples containing WGP have lower porosity value than other waste groups. With the increase of COW and SFC, the porosity value increased. Especially at 30\% of addition, the highest porosity values obtained.

These results can be related to the reactions of waste materials. WGP is a pozzolanic material. It is expected to react with lime and occur C-S-H gels in the structure. C-S-H gels are the main phase of 
cementitious materials, which provide the strength of the matrix. The chemical composition of COW and SFC is probably not sufficient for their participation in chemical reactions. Therefore, they create more voids in the structure. From the view of strength, the increment in pore amount is not desired, but from the view of thermal conductivity, high porosity is the desired situation.

\subsection{Water Absorption}

The water absorption values of the samples are shown in Figure 7. Figure 8 shows the relation between apparent porosity and water absorption.

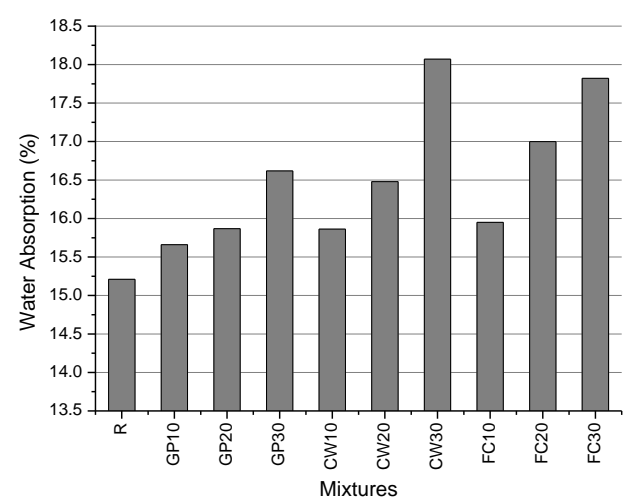

Figure 7. Water absorption values of the samples.

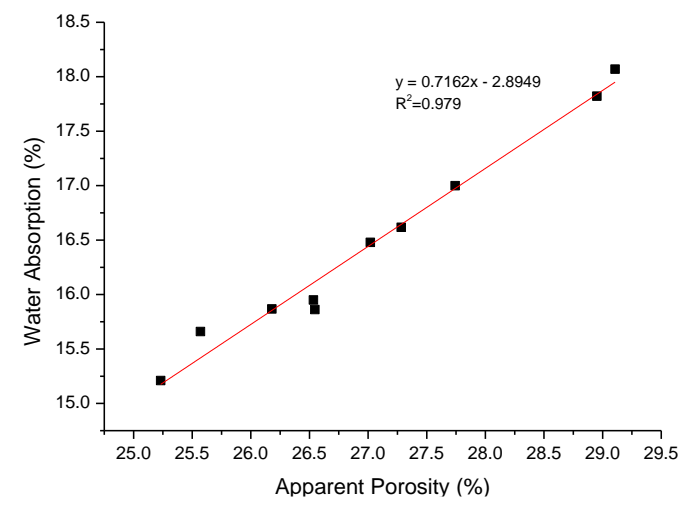

Figure 8. Apparent porosity and water absorption relation.

The water absorption values varied between $15.2 \%-18.1 \%$. The lowest value obtained from the sample R. It can be seen that water absorption values increased with the increase of waste content. The highest water absorption value obtained from CW30. SFC additive was also found to increase waster absorption values, especially when used at high amounts. These results can be related to the pore structure of the material. As seen in section 3.3., high water absorption values were obtained from samples with high porosity. The $\mathrm{R}^{2}$ value is very high, which indicates a strong correlation between these two parameters.

\subsection{Compressive Strength}

The results of compressive strength tests are given in Figure 9. The compressive strength results varied between $7.5 \mathrm{MPa}-19.1 \mathrm{MPa}$. The compressive strengths of the samples were gradually reduced with the addition of waste additives. The highest value belongs to sample R. According to Turkish standards on gypsum plasters [36], various compressive strength limits are specified for different types of gypsum plasters.

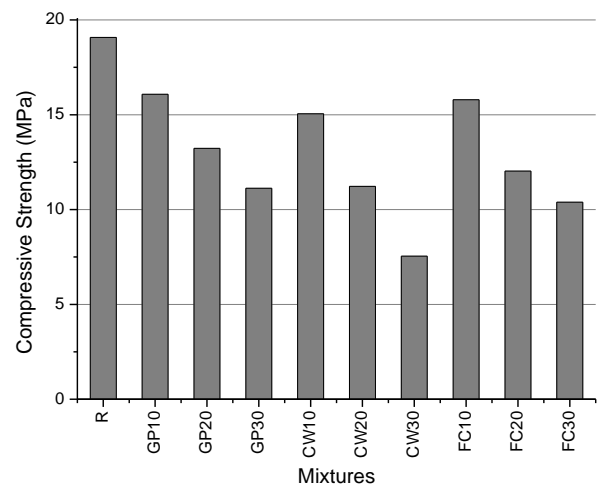

Figure 9. Compressive strength values of samples. 
For most gypsum plaster types, it is considered sufficient to have a compressive strength over 2 $\mathrm{MPa}$, while for some types of gypsum plasters this limit increases up to $6 \mathrm{MPa}$ at most. On the other hand, the highest lower limit for compressive strength of limes for structural application is $5 \mathrm{MPa}$, according to the Turkish standards conforming European norms [37]. As can be seen from Figure 9, the compressive strength values of all the gypsum-lime based mortars are over $6 \mathrm{MPa}$. However, CW30, which has the lowest compressive strength value has a compressive strength loss of $60.7 \%$. The closest result to the reference sample was obtained from the G10 sample. This sample showed a decrease of $15.7 \%$ compared to the sample R.

It is a known fact that porosity has a significant effect on the mechanical properties of the materials. Compressive strength is one of the most important mechanical properties of the structural material. An increase in porosity decreases compressive strength. In the literature, many experimental studies have been conducted on this subject and theoretical equations have been generated. In the studies carried out on gypsum plasters, the relationship between the porosity and compressive strength has been presented experimentally and theoretically [38, 39]. In the light of these data, it will be more meaningful to evaluate the compressive strength results together with porosity results given in section 3.3. It is seen that the amount of pores formed by the use of waste additives significantly affected the compressive strength results.

\subsection{Bending Strength}

The results of bending strength tests are given in Figure 10. The bending strength results varied between 3.4 MPa - 5.7 MPa. The trend of the results is similar to the compressive strength results. The highest value belongs to R sample and the lowest obtained from CW30. Morsy et al. [6] performed bending tests on metakaolin - fly ash - lime - gypsum containing sample and the results varied between 2.2 $\mathrm{MPa}-4.1 \mathrm{MPa}$. In another study performed by Vimmrova et al. [40] on gypsum - lime metakaolin binders, the highest bending strength value was 5.8 MPa. In general, it can be seen that WGP containing samples gave higher bending strength values than other waste containing groups. This may be partly due to the pozzolanic nature of the WGP. Besides, as it can be seen from the results of unit weight, UPV and porosity, the pore-forming effects of other wastes are thought to have a negative effect on bending strength results as the effect on the compressive strength results.

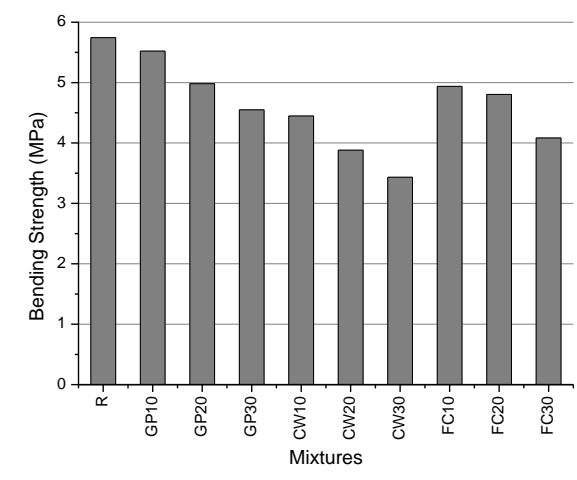

Figure 10. Bending strength values of samples.

\subsection{Thermal Conductivity}

The thermal conductivity coefficients of samples are given in Figure 11. Thermal conductivity decreased with the addition of wastes. The $\mathrm{R}$ sample has a thermal conductivity of $0.894 \mathrm{~W} / \mathrm{mK}$. The lowest value belongs to the CW30 sample, which is $0.557 \mathrm{~W} / \mathrm{mK}$. The closest value to the R sample 
obtained from GP10, which is $0.802 \mathrm{~W} / \mathrm{mK}$. It can be seen that from the figure, waste addition decreased the thermal conductivity coefficient between $10.3 \%$ and $37.7 \%$. The increment in the thermal performance of the sample is related to a decrease in unit weight and an increase in porosity with the addition of wastes. The microstructure of a material strongly affects the thermal conductivity [41]. Vimmarova et al. [40] investigated the thermal performance of gypsum - lime - metakaolin binders and the values changed between $0.198-0.348 \mathrm{~W} / \mathrm{mK}$. The results are quite low, but it should be noted that the water/binder ratio used in the study ranged from 0.7 to 0.85 . Another study [42] based on diatomite added gypsums, which is a very low density and porous material, reported that the thermal conductivity values varied between $0.348-0.497 \mathrm{~W} / \mathrm{mK}$.

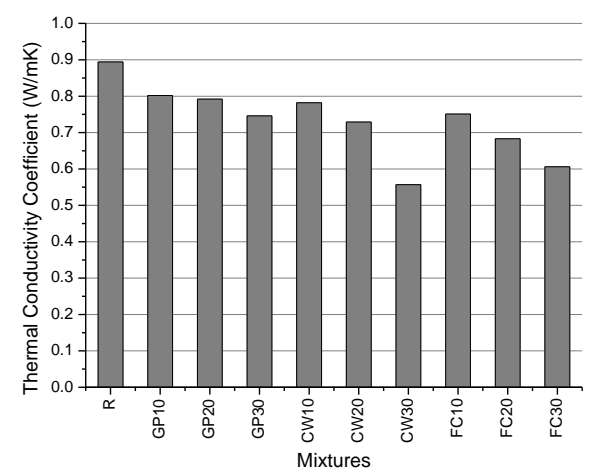

Figure 11. Thermal conductivity coefficients of samples.

\subsection{Scanning Electron Microscopy}

To examine the microstructure of samples, SEM micrographs were taken from some samples. Figure 12 shows the SEM micrographs.

The micrographs were taken from every $10 \%$ and $30 \%$ waste containing sample besides sample R. In these micrographs two basic points are examined. The first one is the porosity and the compactness of the matrix phase and the second one is the quality of the adherence between the aggregate particles and the matrix. From Figure 12a, it can be seen that the matrix phase and the adherence between the matrix and the aggregate are quite denser. This denser structure appears to be looser in the waste added samples. Particularly in the case of COW-containing samples, it can be seen that needle-like gypsum crystals have a much more separate structure. When the adherence condition of the samples examined, it is seen that the aggregate-matrix interface is much looser in samples containing COW and there are significant gaps between aggregates and the paste phase. In samples containing WGP, it can be seen that the paste is more compact and the aggregates are better covered by the paste phase.

\section{Conclusions}

In this study, the use of some waste material in gypsum-lime based mortars was experimentally investigated. According to the data obtained, the following conclusions can be drawn;

- Waste addition slightly decreased the unit weight. In this way a more lightweight product obtained.

- Ultrasonic pulse velocity values decreased with the increase of the waste amount. This is related to the amount of the pores in the body. This finding also confirmed by the results of the apparent porosity test. The highest porosity obtained from CW30. 
- Water absorptions of the samples increase by the increase in waste amount. This is also related to the pore structure.

- The highest compressive and bending strength was obtained from sample R. Waste addition decreased the mechanical properties. This is related to the loose microstructure of the matrix and the aggregate-paste interface.

- Waste addition improved the thermal properties of the samples. The thermal conductivity coefficient decreased between $10.3 \%-37.7 \%$.

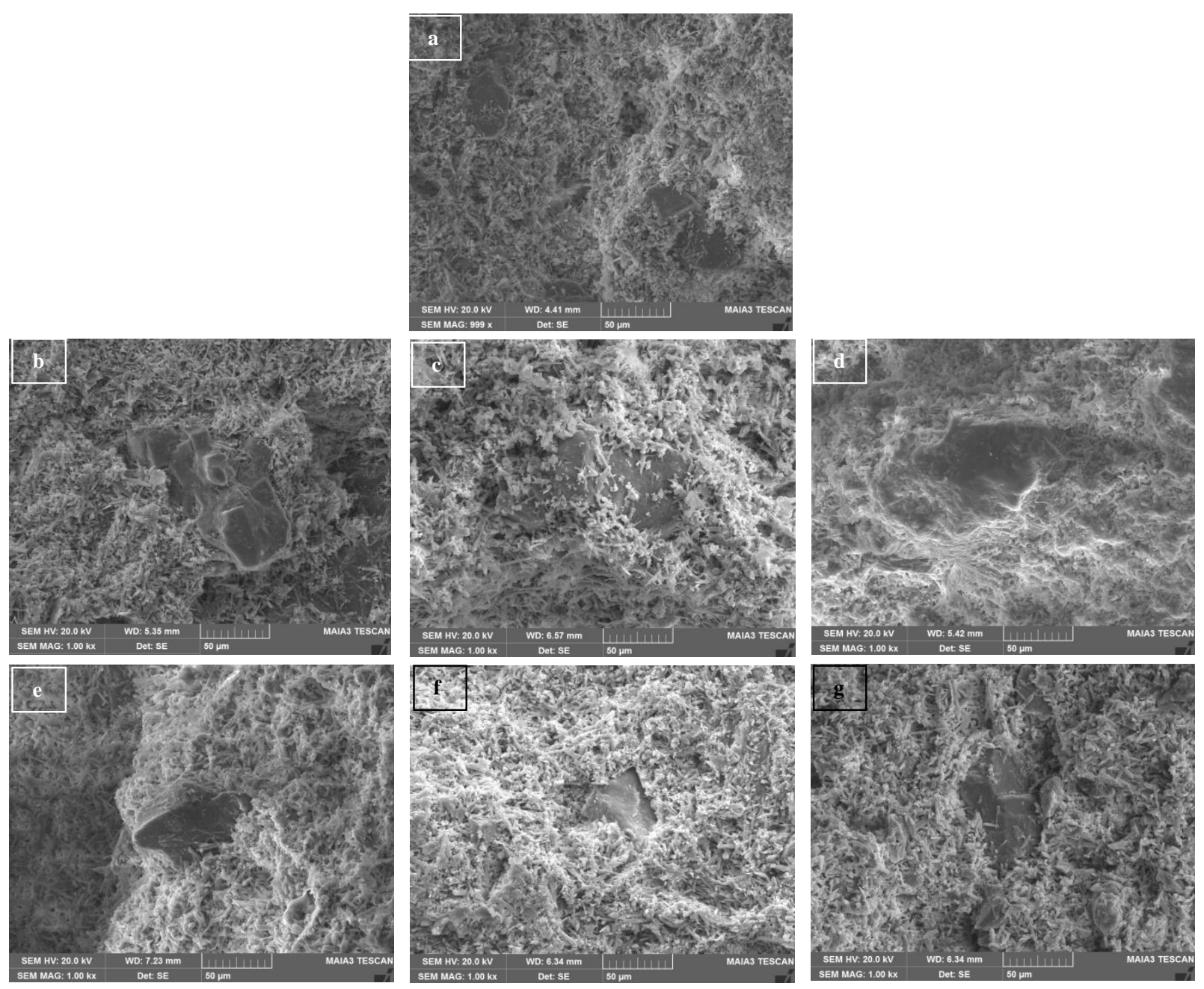

Figure 12. SEM images of a) R b) G10 c) G30 d) S10 e) S30 f) C10 g) C30

\section{References}

[1] Serna, A., del Rio, M., Palomo, J. G., Gonzalez, M., (2012). Improvement of gypsum plaster strain capacity by the addition of rubber particles from recycled tyres, Construction and Building Materials, 35, 633-641.

[2] Biçer, A., Kar, F., (2017). Thermal and mechanical properties of gypsum plaster mixed with expanded polystyrene and tragacanth, Thermal Science and Engineering Progress, 1, 59-65.

[3] Gencel, O., del Coz Diaz, J. J., Sütçü, M., Köksal, F., Alvarez Rabanal, F. P., Martinez-Barrera, B., Brostow, W., (2014). Properties of gypsum composites containing vermiculite and polypropylene fibers: Numerical and experimental results, Energy and Buildings, 70, 135-144.

[4] Barrera-Barbero, M. M., Medina Flores, N., (2018). The effect of polypropylene fibers on graphite-natural hydraulic lime pastes, Construction and Building Materials, 184, 591-601. 
[5] Yilmaz, F., Fidan, D., (2017). Effect of wetting-drying cycles on volumetric stability of clayey soil stabilized with lime and perlite, European Journal of Technique, 7 (2), 2017-2018.

[6] Kamnikas, R., Mituzas, J., Kamnikas, A., (2006). The effect of pozzolana on the properties of the finest fraction of separated Portland cement, Ceramics, 50, 15-21.

[7] Morsy, M. S., Alsayed, S. H., Salloum Y. A., (2012). Development of eco-friendly binder using metakaolin-fly ash-lime-anhydrous gypsum, Construction and Building Materials, 35, 772-777.

[8] Khalil, A. A., Abdel kader A. H., (2010). Preparation and physicomechanical properties of gypsum plaster-agro fiber waste composites, Journal of InterCeram: International Ceramic Review, 21, 62-67.

[9] Wang, Y., Shui, Z., Gao, X., Huang, Y., Yu, R., Ling, G., (2019). Chloride binding behaviors of metakaolin-lime hydrated blends: influence of gypsum and atmospheric carbonation, Construction and Building Materials, 201, 380-390.

[10] Demir, İ., Başpınar, M. S., (2008). Effect of silica fume and expanded perlite addition on the technical properties of the fly ash-lime-gypsum mixture, Construction and Building Materials, 22, 1299-1304.

[11] Gourav, K., Reddy, B. V. V., (2018). Out-of-plane flexure behavior of fly ash-lime-gypsum brick masonry walls, Engineering Structures, 173, 241-250.

[12] Neto, A. A. M., Cincotto, M. A., Repette, W., (2010). Mechanical properties, drying and autogenous shrinkage of blast furnace slag activated with hydrated lime gypsum, Cement and Concrete Composites, 32, 312-318.

[13] Del Rio Merino, M., Astorqui, J. S. C., Saez, P. V., Jimenez, R. S., Cortina, M. G., (2018). Eco plaster mortars with addition of waste for high hardness coatings, Construction and Building Materials, 158, 649-656.

[14] Khalil, A. A., Tawfik, A., Hegazy, A. A., El-Shahat, M. F., (2014). Effect of some waste additives on the physical and mechanical properties of gypsum plaster composites, Construction and Building Materials, 68, 580-586.

[15] Aubert, J. E., Segui, P., Husson, B., Measson, M., (2012). A method developed to quantify lime and gypsum consumed by mineral additions, Cement and Concrete Composites, 34, 874-880.

[16] Massazza, F., (1998). "Pozzolana and Pozzolanic Cements" in Lea's Chemistry of Cement and Concrete, Butterworth-Heinemann, 471-635.

[17] PAGÇEV, Atık İstatistikleri. http://www.pagcev.org/atik-istatistikleri. 2007. Accessed: 07.09.2019.

[18] Lu, J. X., Zheng, H., Yang, S., He, Pingping, Poon, C. S., (2019). Co-utilization of waste glass cullet and glass powder in precast concrete products, Cons. Buit. Mat., 223, 210-220.

[19] Du, H., Tan, K. H., (2017). Properties of high volume glass powder concrete, Cement and Concrete Composites, 75, 22-29

[20] Ling, T. C., Poon, C. S., (2014). Feasible use of large volumes of GGBS in 100\% recycled glass architectural mortar, Cement and Concrete Composites, 53, 350-356.

[21] Vaitkevicius, V., Serelis, E., Hilbig, H., (2014). The effect of glass powder on the micro-structure of ultra high performance concrete, Construction and Building Materials, 68, 102-109.

[22] Redden, R., Neithalath, N., (2014). Microstructure, strength, and moisture stability of alkali activated glass powder-based binders, Cement and Concrete Composites, 45, 46-56.

[23] Durgun, M. Y., Sevinç, A. H., (2019). High temperature resistance of concretes with GGBFS, waste glass powder, and colemanite ore wastes after different cooling conditions, Cons. Built. Mat., $196,66-81$. 
[24] Papadakis, V. G., Tsimas, S., (2002). Supplementary cementing materials in concrete Part I: efficiency and design, Cement and Concrete Research, 32, 1525-1532.

[25] Sevim, U. K., (2011). Colemanite ore waste concrete with low shrinkage and high split tensile strength, Materials and Structures, 44, 187-193.

[26] Olgun, A., Kavas, T., Erdogan Y., Once G., (2007). Physico-chemical characteristics of chemically activated cement containing boron, Building and Environment, 42, 2384-2395.

[27] Ochoa, G. P. A., Eras, J. J. C., Gutierrez, A. S., Hens, L., Vandecasteele, C., (2010). Residue from sugarcane juice filtration (filter cake): Energy use at the sugar factory, Waste and Biomass Valorization, 1, 407-413.

[28] Makul, N., Sua-iam, G., (2016). Characteristics and utilization of sugarcane filter cake waste in the production of lightweight foamed concrete, Journal of Cleaner Production, 126, 118-133.

[29] Yaduvanshi, N. P. S., Yadav, D. V., (1990). Effect of sulphation press mud and nitrogen fertilizer on biomass, nitrogen economy and plant composition in sugarcane and soil chemical properties, The Journal of Agricultural Science, 114 (3), 259-263.

[30] Neha, G., Sumit, T., Chandrajit, B., (2011). Characterization of press mud: a sugar industry waste, Fuel, 90, 389-394.

[31] Li, H., Xu, J., Wu, J., Xu W., Xu, Yan, (2012). Influence of sugar filter mud on formation of Portland cement clinker, Journal of Wuhan University of Technology, 28 (4), 746-750.

[32] Li, H., Xu, W., Yang, X., Wu, J., (2014). Preparation of Portland cement with sugar filter mud as lime-based raw material, Journal of Cleaner Production, 66, 107-112.

[33] James, J., Pandian P. K., (2016). Geoenvironmental application of sugarcane press mud in lime stabilization of an expansive soil: a preliminary report, Australian Journal of Civil Engineering, 14 (2), 114-122.

[34] Mansoor, A. M., Visgai, P., Sumeha, P. S., Swathi, K., Sowmiya, R., (2017). Utilization of sugar mill waste in manufacturing of bricks, International Journal of Engineering Research and Technology, 5 (13), 1-5.

[35] Tesch, V., Middendorf, B., (2006). Occurrence of thaumasite in gypsum lime mortars for restoration, Cement and Concrete Research, 36, 1516-1522.

[36] TS EN 13279-1, Gypsum binders and gypsum plasters - Part 1: Definitions and requirements, February 2009, Turkish Standards Institute, Ankara.

[37] TS EN 459-1, Building lime - Part 1: Definitions, specifications and conformity criteria, 2015, Turkish Standards Institute, Ankara.

[38] Bu, J., Tian, Z., (2016). Relationship between pore structure and compressive strength of concrete: Experiment and statistical modeling, Sadhana, 41 (3), 337-344.

[39] Schiller, K. K., (1971). Strength of porous materials, Cement and Concrete Research, 1 (4), 419422.

[40] Vimmrova, A., Keppert, M., Michalko, O., Cerny, R., (2014). Calcined gypsum-lime-metakaolin binders: Desing of optimal composition, Cement and Concrete Composites, 52, 91-96.

[41] Sevim, D., Fidan, Ş., Polat, S., Oktay, H., (2017). Experimental and articial neural network based studies on thermal conductivity of lightweight building materials, European Journal of Technique, 7 (1), 33-41.

[42] Gencel, O., del Coz Diaz, J. J., Sutcu, M., Koksal, F., Alvarez Rabanal, F. P., Martinez-Barrera, G., (2016), A novel lightweight gypsum composite with diatomite and polypropylene fibers, Construction and Building Materials, 113, 732-740. 